\title{
California tackles insurance
}

\section{Washington}

THE California state legislature is poised to pass a bill that would place an eight-year ban on the use of genetic information to discriminate among people in selling health insurance. If the bill is not vetoed by Governor Pete Wilson, California will become the first state to prevent health insurers from using the results of genetic tests to influence underwriting decisions.

The bill, sponsored by Lloyd Connelly, a California Democrat, would also ban the use of genetic test information in employment decisions. The original draft proposed an indefinite ban on health insurers using genetic test results, but in a compromise to reduce opposition from the insurance industry, the bill emerged from the state Senate Judiciary Committee last month with the health insurance ban curtailed to an eight-year moratorium.

The bill is now expected to be passed by the legislature within a matter of days, and then needs only the governor's signature to become law. Wilson's aides say he has not yet taken a position on the bill.

Coming from the most populous state in the country, legislation in California is watched carefully - though not necessarily imitated - by other states. Given that the Human Genome Project is likely to yield many new diagnostic tests for genetic diseases over the next decade, Steve Brown from the Council of State Governments says he expects many states to regulate the use of genetic information over the next few years. But he says it is difficult to predict how other states will act on the controversial issue of health insurance.

Insurance companies argue that genetic test results are no different from the other medical data they use in underwriting health insurance. The industry fears that if applicants for health insurance are able to withhold genetic information, those whose genetic test results reveal that they are likely to have high health care costs will seek out health insurance in greater numbers. The result would eventually be higher outlays for insurance companies, and the undermining of the industry, insurers say. Nevertheless, Brad Wenger, from the Association of California Life Insurance Companies (which also represents the state's health insurers), says his organization has dropped its opposition to Connelly's bill because most companies do not expect to use genetic information on a large scale over the next eight years. By the end of that period, he says, the federal government will probably have passed legislation on the issue.

On the other hand, some medical geneticists argue that genetic information is fundamentally different from the other data used by health insurers. If tests become available to identify a wide range of genes that confer susceptibility to particular health problems, they say, the whole notion of 'shared risk' that underlies the insurance business will be subverted, and people whose genetic makeup indicates a higher probability of illness will find it difficult to get affordable health insurance. (See also page 2.)

Paul Billings, a geneticist at the California Pacific Medical Center who helped Connelly to draft his bill, believes legislation is needed now because, he says, some companies are already beginning to discriminate unfairly against people with genetic disorders. For example, he says, there have been several instances of people with phenylketonuria - a disorder that can be treated successfully simply by observing a special diet — being denied health insurance.

California has a reputation for moving quickly to regulate the insurance industry to take account of new medical developments. In 1985, shortly after the introduction of the first blood test for human immunodeficiency virus (HIV) infection, the state legislature banned health and life insurers from using these test results. The health insurance restrictions remain, but the life insurance ban was repealed once it became known that the majority of people infected with HIV go on to develop AIDS.

Peter Aldhous

\section{SCIENTIFIC SOCIETIES}

\section{Ethics rules provoke storm}

\section{Washington}

D. Allan Bromley, science adviser to President George Bush, may soon be asked by many of the leading US scientific societies to secure changes to new government ethics rules that the societies say could undermine their very existence. At a meeting in Washington last week, representatives from more than 15 scientific societies decided to seek a meeting with Bromley to explain their opposition to proposed rules that could, they say, prevent government researchers from serving as society officers.

In late July, the Office of Government Ethics proposed a wide-ranging revision of its ethical standards for all employees of the US government's executive branch. Most of the rules are uncontroversial for example, a prohibition on government employees receiving gifts from people with whom they do business - but the new section on 'outside activities' has sent a frisson of panic through the science societies. According to some interpretations, the rules would prohibit government scientists from doing almost any society work on government time. The societies fear the rules would demand that government researchers editing journals or organizing meetings on behalf of their societies should do this in their spare time.

The societies argue that the proposed rules would make government researchers into the 'second class citizens' of the scientific community, unable to participate fully in their professional organizations. Worse still, universities and industrial employers might follow the government example and also place restrictions on researchers working for scientific societies during work hours.

One attorney at the Office of Government Ethics explains that the rules are designed to prevent society officers from using government time to conduct routine society business, such as contacting mem- bers to remind them to pay their subscriptions. But the rule would allow a government researcher to attend a society conference if the subject is directly related to the mission of the researcher's agency. As to whether government scientists would be allowed to organize a conference or edit a society journal, the attorney says these are "grey areas" that will need further thought.

Many science society officials argue that the proposed rules would also hurt the government. The progress of science depends partly on the existence of societies to promote conferences and publish journals, they argue, and if the societies are damaged by the new rules, then the government, as the largest funder of science in the United States, will also suffer.

Stressing the disadvantages to the government if its researchers are prevented from working for their professional societies may be the best way to attack the proposed rules, but the coalition of scientific societies faces a difficult dilemma: how to exert maximum influence within the US Administration, while attracting a minimum of press attention. In the wake of a series of well-publicized scientific misconduct investigations, many journalists are now primed to view scientists as cheats. So any suggestion that researchers are seeking to use government time to further the ends of their professional societies is unlikely to attract favourable coverage.

The delegation to Bromley, assuming that he agrees to the meeting, is expected to consist of four or five prominent society presidents. But for many of the societies gathered at last week's meeting, the immediate priority is to obtain an extension to the period allowed for public comment on the rules. Unless the Office of Government Ethics allows an extension, the societies have only until 20 September to produce their responses.

Peter Aldhous 